\title{
ВИКОРИСТАННЯ КОМП'ЮТЕРНИХ ТЕХНОЛОГІЙ ТА МОЖЛИВОСТЕЙ ІНТЕРНЕТ У ПРАКТИЦІ ВИКЛАДАЧА ВИЩОЇ ШКОЛИ
}

\author{
О. В. Ковальова, О. В. Ковальова ${ }^{1}$ \\ ДЗ «Запорізька медична академія післядипломної освіти МОЗ України» \\ ${ }^{1}$ Запорізький національний технічний університет

\section{THE USAGE OF COMPUTER TECHNOLOGIES AND INTERNET OPPORTUNITIES IN THE UNIVERSITY TEACHER PRACTICE} \\ O. V. Kovaliova, O. V. Kovaliova ${ }^{1}$ \\ SI «Zaporizhzhia Medical Academy of Postgraduate Education MH of Ukraine» \\ ${ }^{1}$ Zaporizhzhia State Medical University
}

Вступ. Величезний масив знань, одержуваних із різних джерел, хвилею накриває тих, хто вчиться. Тому завдання вищої школи бути провідником, здатним вивести на вірний шлях адекватної оцінки одержуваної інформації, сприяти напрацюванню навиків їі використання.

Цикли вдосконалення на базі ЗМАПО тривають найчастіше лише один місяць. За цей час необхідно не тільки вірно подати матеріал, а й навчити вибірково ставитися до інформаційного потоку, раціонально працювати 3 Інтернет-ресурсами.

Відкривається новий шлях в освіті, що полягає у використанні комп'ютерних технологій. При цьому дистанційне навчання $€$ найважливішим компонентом системи відкритої освіти.

Від рівня інформаційно-технологічного розвитку його темпів, рівня подачі матеріалу залежать стан освіти і, відповідно, її якість.

Результати та їх обговорення. Скорочення кількості годин педагогічного навантаження на кожного викладача передбачає самостійну роботу студента за допомогою презентацій, електронних книг, статей тощо. Посилання викладаються на електронну скриньку чи інформація передається на диску. Викладачеві головне пояснити суть завдання/теми, а далі кожен працює з отриманим матеріалом у зручний для себе час, i, найголовніше, в звичному для свого сприйняття ритмі.
Як показують опитування, нові інформаційні технології залучають слухачів іє одним із головних їхніх інтересів. Тобто у формі гри використання інформаційних технологій у навчальному процесі сприяє формуванню позитивної мотивації до навчання. При тому це дуже зручно, оскільки зв'язок із викладачем підтримується постійно в зручному для всіх режимі.

Відпрацьовується певний алгоритм, коли об'єкт дискусій має форму комп'ютерної гри. Психологія людської істоти така, що гра сприяє якісному засвоєнню матеріалу через мотивацію азарту. Тобто щоб перейти на вищий рівень треба вже мати суму деяких знань. Деякі викладачі кажуть, що втрачається клінічне мислення. Загалом, звичайно, на це $\epsilon$ підстави. Коли трапляеться лихо, рахунок йде на секунди. При реанімації 1 хвилина бездіяльності забирає $10 \%$ життя. Тут має місце тільки алгоритм лікування за синдромом (стандарти НАТО). Від того, як своєчасно та кваліфіковано надано допомогу, залежить здоров'я і навіть життя пацієнта. А от у скороченні годин педнавантаження та збільшенні годин на самостійну роботу в такому сенсі немає проблеми. Необхідно просто змінити структуру роботи, сприяти зацікавленості тих, кого ми навчаємо.

Висновок. Застосування інформаційних технологій $\epsilon$, можливо, найкориснішим при індивідуалізації викладання. 